UDC 504.062:330.15
JEL: Q320,H230

Katerina Kostetska

Ph.D. in economics, Institute of Market Problems and Economic and Ecological Research NAS of Ukraine, Odessa, Ukraine E-mail: kathryn81@ukr.net orcid.org/0000-0003-0378-7681

\section{Marzena Smol}

Doctor of Technical Sciences, Mineral and Energy Economy Research Institute of the Polish Academy of Sciences, Cracow, Poland E-mail: smol@meeri.pl orcid.org/0000-0001-5833-2954

\section{Krzysztof Gaska}

Doctor of Technical Sciences, Professor,

Silesian University of Technology, Gliwice, Poland E-mail: krzysztof.gaska@polsl.pl orcid.org/0000-0002-9369-6144

Received: October, 2018

Accepted: December, 2018

DOI:10.31520/2616-7107/2018.2.4-4

(C) Economics. Ecology. Socium, 2018 CC BY-NC 4.0 license

\section{RATIONAL NATURE USE OF RECREATIONAL MANAGEMENT SUBJECTS ON THE BASIS OF INCLUSIVE}

Introduction. The existing state of the use of natural resources by recreational management subjects showed problems in the legislative framework regarding methodical explanations of the calculation of rental payments for extraction and use of recreation resources of the recreation management subjects have been identified. The directions of management of the recreation management subjects with attraction of recreational resources on the basis of an inclusive approach are offered. Tax liabilities of the recreation management subjects using natural resources fall into the state budget, and they have to local with them further provision in the form of privileges for improving the ecological situation of recreational and tourist territory.

Aim and tasks. The purpose of the article is to provide suggestions for improving management in the field of recreation and tourist use of nature, for example, the use of natural resources of the recreation management subjects on the basis of inclusive. The goal is to fulfill the following tasks: to generalize the existing state of management in the field of the recreation management subjects; provide suggestions on how to improve the management of recreation management subjects, which use recreation resources on an inclusive basis.

Results. The article substantiates the necessity of administrative management in the recreational and tourist nature management on the basis of inclusive, namely, it is necessary to transfer the rights of state control over the extraction of medical resources to the local level, to improve the system of fiscal and tax control over the recreation management subjects with using recreation resources, etc. Recommendations of improvement financial regulation due to attraction of private entrepreneurship in compliance with requirements of environmental quality standards, standards of environmental impact, technological standards; product quality standards; environmental certification, etc. It is proved that the distribution of taxes from economic activity should come not only to the state budget, but also to the local. At the same time, taxes that come to the local budget should be used as subsidies to improve the ecological state of the same territory.

Conclusions. The general conclusion is that integrated management of recreational resources and the recreational management subjects should provide implementation horizontal functions that are specific to the type of administrative activity that affects the using by recreational management subjects national natural resources of various forms of ownership. Need a clear economic justification and calculation of tax and rent income from the recreational management subjects using of natural resources. So it is necessary to amend the calculation of rent payments for the use of medical resources to increase them and prescribe methodical recommendations for their determination. It have to ensure simultaneous, common, in one economic-ecological plane for all administrative subjects horizontal and vertical branches of compliance with the principles of inclusiveness in nature management.

Keywords: recreational management subjects, administrative management, inclusive. 


\section{УДК 504.062:330.15 \\ JEL: Q320,H230}

\section{Катерина Костецька}

Кандидат економічних наук, Інститут проблем ринку та економіко-екологічних досліджень НАН України, Одеса, Україна

E-mail: kathryn81@ukr.net orcid.org/0000-0003-0378-7681

\section{Маржена Смол}

Доктор технічних наук, Дослідницький інститут економіки та енергетики Польської академії наук, Краків, Польща

E-mail:smol@meeri.pl orcid.org/0000-0001-5833-2954

\section{Кшиштоф Гаска}

Доктор технічних наук, професор, Сілезький технологічний університет, Глівіце, Польща E-mail: krzysztof.gaska@polsl.pl orcid.org/0000-0002-9369-6144

Отримано: Жовтень, 2018 Прийнято: Грудень, 2018

DOI:10.31520/2616-7107/2018.2.4-4

(C) Економіка. Екологія. Соціум, 2018 CC BY-NC 4.0 ліцензія

\section{РАЦІОНАЛЬНЕ ПРИРОДОКОРИСТУВАННЯ СУБ'СКТАМИ РЕКРЕАЦІЙНОГО ГОСПОДАРЮВАННЯ НА ЗАСАДАХ ІНКЛЮЗИВНОСТІ}

Вступ. Існуючий стан використання природних ресурсів суб'єктами рекреаційного господарювання засвідчив проблеми в законодавчій базі щодо методичних роз'яснень розрахунку рентних платежів видобутку та використання рекреаційних ресурсів суб' єктами рекреаційного господарювання. Більшість податкових зобов'язань суб'єктів рекреаційного господарювання 3 використанням природних ресурсів не спрямовані до місцевих бюджетів 3 їх подальшим наданням суб'єктам рекреаційного господарювання у вигляді пільг на удосконалення екологічного становища рекреаційно-туристичної території.

Мета та завдання. Метою статті є надання пропозицій щодо вдосконалення управління в сфері рекреаційнотуристичного природокористування на прикладі використання природних ресурсів суб'єктами рекреаційного господарювання на засадах інклюзивності. Поставлена мета потребує виконання наступних завдань: узагальнити існуючий стан управління в сфері діяльності суб'єктів рекреаційного господарювання; надати пропозиції щодо напрямів вдосконалення управління суб'єктами рекреаційного господарювання, які використовують рекреаційні ресурси на засадах інклюзивності.

Результати. Обгрунтовано засади адміністративного управління в рекреаційно-туристичному природокористуванні на засадах інклюзивності, а саме необхідно передати права державного контролю за видобутком лікувальних ресурсів до місцевого рівня, удосконалити систему фіскального та податкового контролю за діяльністю суб'єктів рекреаційного господарювання з використанням рекреаційних ресурсів, тощо. Наведено рекомендації щодо поліпшення регулювання завдяки залученню приватного підприємництва 3 дотриманням вимог стандартів якості навколишнього середовища, стандартів впливу на навколишнє середовище, технологічних стандартів; стандартів якості продукції; екологічної сертифікації, тощо. Запропоновано напрями розподілу податків для подальшого їх використання як дотації на поліпшення екологічного стану території.

Висновки. Комплексне управління рекреаційними ресурсами має передбачати здійснення ряду поєднаних по горизонталі специфічних функцій, що визначають види адміністративної діяльності, які впливають на використання загальнонародних природних ресурсів суб'єктами рекреаційного господарювання різних форм власності. Необхідне чітке економічне обгрунтування та розрахунок податкових та рентних надходжень від використання природних ресурсів суб'єктами рекреаційного господарювання. Потрібно внести поправки до розрахунку рентних платежів за використання лікувальних ресурсів до їх збільшення та прописати методичні рекомендації до їх визначення. Для цього необхідно забезпечити одночасне, спільне, в одній економіко-екологічній площині для всіх управлінських суб'єктів по горизонталі та вертикалі галузей дотримання засад інклюзивності в природокористуванні.

Ключові слова: суб'єкти рекреаційного господарювання, адміністративне управління, інклюзивність. 
Introduction. Ensuring the economically oriented development in the Ukrainian recreation sphere is compounded by global trends in development of services, among which priority is the recreation and tourist activity. At the same time relevant in the context of growing demand for recreation services by the Ukrainian population associated with a decrease in the level of health, the presence of depopulation tendencies, an increase in the level of cultural and cognitive needs of the population of Ukraine, and so on. But the lack of effective management of the recreation and tourist potential of Ukraine for a long time restrained the development and prevented the effective functioning of the recreation sphere and the sustainable development of the recreational management subjects as a whole of the country and its individual regions.

Among the more relevant studies on the issues in recreation sphere and directions of inclusive are scientific works B.V. Burkinsky, V.V. Velichko, A.I Martyenko, L.A. Deineko, N.I. Khumarova, B.M Danylyshina, [1,2,3,4,5], R. Samans, J.Blanke [6], M. Drzeniek Hanouz, R. Ranieri, R. A.Ramos [7] and others.

Selection of the previously unresolved issues that is a part of the general problem that the article is devoted to. For a long time there were accumulated problems that have a negative impact on the economic efficiency of the use of existing recreation and tourist potential of Ukraine. Among them are large carloading: weak innovation and investment activity in the formation and use of recreational potential of the regions of Ukraine; lack of investment in the purpose and limitation of foreign investments (special long-term) in the development of recreation sphere; insufficient use of resort health areas and medical resources, etc.

The aim. So important is to find incluse methods of using unified approach to administering the work of the recreational management subjects by conducting an economic assessment of the total use of natural resources based on extraction, use in spa treatment, and the manufacture of products through the use of eco-management tools, namely, the economic analysis of all aspects of the organizational, production process and product movement from the point of view the concept of an ecological life cycle, carrying out of an economic and environmental audit of the recreational management subjects.

Results. Today, the principles of inclusive are observed everywhere, as in the economy, politics, social development. However, with regard to resource use, the notion of inclusiveness is considered only from an economic point of view. Important is the introduction of the principles of inclusiveness in resource use. A striking example is Israel's practice of extracting and using Dead Sea therapeutic resources. Thus, budget revenues from the introduction of the hotel business amounted to 0.317 billion. Of these, recreational activities involving the use of Dead Sea therapeutic procedures amount to $\$ 31$ million [9], which is practically $10 \%$ of the total volume. Regarding the tax system for the introduction of economic activities in Israel using recreation and tourist resources, the taxes are distributed as follows: income tax - 36\% and tax on the use of medical resources - $25 \%$ [10]. Such a system of administrative management of entrepreneurial activity with the use of medical resources is very relevant for Ukraine. For example, in Ukraine, the rent for the production of medical resources is $5 \%$ [11] of the value of commodity products and is calculated by taxpayers independently on the basis of primary accounting data.

Recent studies on the protection of the Dead Sea have shown that a large amount of salt can lose this national natural wealth and is already fraught with flooding of foundations located on the coast of hotels. Therefore, with the aim of lowering its tax provisions, the company "Kemikalim le Israel" [12], which is the sole lessee of the share of the sea for the production of medical mud, has signed an agreement with Netherlands company Holland Shallow Seas Dredging for the first stage of the salt harvest project. The cost of the contract is estimated at 28.6 million dollars [12], and the total cost of the project to protect the hotels of the Dead Sea from flooding is $\$ 200$ million. $80 \%$ of this amount will be paid by "Kimikalim le Israel", the rest - the state [12]. 
The salt extracted from the bottom of the sea is planned to be recycled to produce potash from it - a substance that is actively used in the production of glass, in painting and photography. According to the agreement reached, the company "Kimikalim le Israel" will pay "lease" of the Dead Sea, where salt extraction will be carried out. With further sales of more than two tons per year, the company "Kimikalim le Israel" will pay the state $10 \%$ of the total profit, and if the sale does not reach the specified amount then $5 \%$ of the amount [12].

International experience testify that the state regulates and controls all economic activities in the recreational and tourist sphere; the state regulates international agreements for the Dead Sea salvage through: attracting foreign investment for salvation, that is Dutch company Holland Shallow Seas Dredging invests its equipment in salvation of the legacy of Israel, and the state provides preferential promotion of the company's equipment to the water supply and water treatment system of the country. The state, as the owner of recreation and tourist resources and the only controlling body, is able not only to overcome the excessive burden on the natural resource potential, but also to replenish the budget through ecologically oriented business activities.

In Ukraine there are many gaps in the operation of the recreational management subjects with the use of natural resources, namely, there is no clear link between the stages of obtaining a license for extraction, balneological conclusion and state control over the work of the recreational management subjects. All this has led to the fact that there is no single database regarding the availability of natural resources and their valuation in monetary terms. Such a situation leads to a certain contradiction between the interests of the state in the use of these resources and private actors in their treatment. Very often valuable natural resources are used not in their direct direction or are involved in economic circulation through the use of other natural resources located with them, which leads to economic and ecological losses of valuable medicinal natural resources. It should be emphasized that all natural resources as a whole, as well as the recreational management subjects, are in different administrative subordination at different levels of government, which leads to uncontrolled extraction and use. So, the urgent need is decentralization with amendments to the Tax and Administrative Codes of Ukraine. There is a need to introduce some levers on compliance with the requirements set out in the legislative framework and do not function today (Table 1).

Administrative management in the field of natural resources in economic circulation should ensure:

1. Conducting inventories of natural resources with the definition of their volumes and recreational management subjects, which use them for the time being.

2. Introduction of potential inventories of natural resources that can be introduced into economic circulation.

3. Accounting of all natural resources that are in economic circulation and potentially can be put into economic circulation. This function is very important, since today there are no inventories of potential natural resources, ie, licenses for activities and their placement are issued without taking into account the natural resources that can be used as therapeutic.

4. Inventories of natural resources should reflect all subjects of activity, including recreational management subjects that have an impact on them.

Thus, the administration of natural resources is a coordinated activity of state authorities on the rational redistribution, use, restoration, protection and regulation of the recreational management subjects work, while respecting the limitations of economic and environmental significance and financial control. However, today the state administrative management of natural resources and the recreational management subjects are actually practical activities of non-interconnected horizontally different state bodies in terms of activities and regulatory levels. The policy of dealing with natural resources should be considered in inclusive basis, as a sphere of realization of social, economic and environmental interests by making managerial decisions and establishing a system of administration for the realization of these interests. 
Table 1. Existing state and directions of improvement of administrative management in the field of the use of medical resources

\begin{tabular}{|c|c|}
\hline Existing state & \\
\hline \multicolumn{2}{|r|}{ Medical resources cadastre } \\
\hline $\begin{array}{l}\text { Cadastre of Ukrainian medical resources, } \\
\text { which shows the location and kind of } \\
\text { resource }\end{array}$ & $\begin{array}{l}\text { - detailed accounting of medical resources, in both natural and } \\
\text { monetary equivalents; } \\
\text { - availability of economic, ecological and social data on medical } \\
\text { resources; } \\
\text { - consideration of polyfunctionality of the medical resource and } \\
\text { their priority use in the main direction }\end{array}$ \\
\hline \multicolumn{2}{|c|}{ Permission for the extraction of medical resources } \\
\hline $\begin{array}{l}\text { - ease of obtaining permission; } \\
\text { - permission is issued for almost } 20 \text { years; } \\
\text { - automatic prolongation of permission; } \\
\text { - the volume of the medical resource is } \\
\text { indicated at the time of obtaining the } \\
\text { permit; } \\
\text { - balneological conclusion; }\end{array}$ & $\begin{array}{l}\text { - the volume of the extraction of medical resources should be } \\
\text { indicated; } \\
\text { - ecological and economic substantiation of volumes of } \\
\text { extraction without harm to the environment; } \\
\text { - introduction of a requirement for the use of medical resources; } \\
\text { - introduction of control functions: environmental, economic } \\
\text { and financial }\end{array}$ \\
\hline \multicolumn{2}{|c|}{ Supervision of authorities in the work of the recreational management subjects } \\
\hline $\begin{array}{l}\text { - simplified procedure for issuing permits } \\
\text { for the extraction of medical resources; } \\
\text { - expert examination at the expense of the } \\
\text { state for state enterprises and recreational } \\
\text { management subjects with the sphere of } \\
\text { activity: recreation sphere; health- } \\
\text { rehabilitation sphere; } \\
\text { - reception of the balneological conclusion }\end{array}$ & $\begin{array}{l}\text { - introduction of administrative penalties, both from the subjects } \\
\text { of management and from the authorities for failure to provide } \\
\text { information; } \\
\text { - dissemination of public control in the field of the extraction } \\
\text { and use of medical resources; } \\
\text { - introduction of administrative, environmental and } \\
\text { administrative and financial control levers, with their } \\
\text { consolidation in legislation }\end{array}$ \\
\hline
\end{tabular}

Source: compiled by the authors.

There are no parameters for calculating the appropriateness of the use and extraction of natural resources, both in view of the economic profit from consumption and the environmental component of causing damage or damage from the use of the resource. It is necessary to consider in more detail the economic feasibility of using natural resources. The recreational management subjects use of recreational resources is through the provision of natural resources for use or at the expense of the payment for the special use of natural resources, according to the law on mineral resources.

Tax liabilities from rent for the use of subsoil, including curative resources within a single subsoil within the tax (reporting) period are calculated by the following formula [11]:

$$
P s n=V c \times C u \times V r m r \times C m r,
$$

where $V c$ - volume (quantity) of the corresponding type of subsoil - extracted minerals in the tax period (in units of mass or volume); $\mathrm{Cu}$ - the cost of a unit of the type of subsoil;

The cost of the relevant type of subsoil extracted mineral resources is established at the actual prices of the sale or at the estimated value of the corresponding type of commodity products. However, if actual sales prices for commodity products from oil, non-ferrous metals and ore and gas are published monthly on the site of the central executive authority, then information on actual prices for medical resources is absent.

$V r m r$ - the value of the rent for the use of mineral resources for the extraction of minerals (in percentages), for medical resources it is $5 \%$;

$\mathrm{Cmr}$ is a corrective factor that is not available for medical resources. Also, the tax provisions of the recreational management subjects include a profit tax of $18 \%$ and a value added tax of $20 \%$, which is added to the price of the goods and is a national tax. 
At the same time, if consider the total recreational management subjects activity with the extraction and sale of products from natural resources, it can be stated that such operations as carrying out hygienic examination of samples of new types of products, inspection at the request of the customer of the under construction, reconstructed or operated, in order to comply with sanitary legislation; carrying out on request of the customer toxicological-hygienic, medical-biological, sanitary-hygienic, physiological and other surveys for the purpose of determining the safety of products for human health are exempt from taxation.

Another problem is the tax control recreational management subjects work with the use of medical resources. Today, tax control is carried out by:

- keeping records of taxpayers;

- information and analytical support for the activities of the controlling bodies;

- inspections and inspections in accordance with the requirements of law;

- monitoring of controlled operations and interviewing officials, authorized persons and / or employees of the taxpayer, respectively.

The legislation provides for the recreational management subjects reporting to fiscal authorities on the basis of data that the enterprise identifies on its own, while the controlling function of the authorities is used only in the circumstances of the violations of the work of the recreational management subjects or in the specified terms for 3-5 years. However, modern practice proves that control over the recreational management subjects activities is almost non-existent.

Thus, it is very difficult to form a single methodological approach to calculating rental rates for the recreational management subjects using natural resources. Currently, there are no methods for calculating the tax rates for the introduction of the recreational management subjects on the basis of the use of natural resources, and there is virtually no monitoring power of the authorities regarding the extraction, production and sale of the resource itself and its products, while recreational management subjects operate only on the basis of permits and licenses.
It is necessary to prescribe the general methodological recommendations for conducting the recreational management subjects with the extraction of medical resources taking into account:

- economic assessment of natural resources which should be carried out on the basis of the State cadastre; clear legislative submissions regarding the size of tax provisions for the extraction, use, production from the natural resources of the recreational management subjects;

- clear rent rates for the use of natural resources and the normalization of actual pricesfor actually manufactured products;

- tax and credit privileges;

- clear control by the local authorities of the recreational management subjects activities and reported it.

Thus, while making manager decisions of tourist-recreation territory development with using natural resources, its necessary the following stages:

I. Analysis of the environmental feasibility of the recreational management subjects, given that they have permission and license for the extraction and use of natural resources.

II. Economic justification and calculation of tax and rent revenues from the recreational management subjects use of natural resources.

III. Areas of development of alternative activities of the recreational management subjects using natural resources.

IV. Attraction of investments or state subsidies, privileges on expansion of the recreational management subjects.

V. Granting authority to local authorities to control the full cycle of the recreational management subjects activities from the production of natural resources to the production of products from them (involving independent auditors in verifying the enterprise's activities).

In this case, the conceptual directions of administrative regulation of the recreational management subjects work with the involvement of natural resources should become (Table 2). 
Table 2. Areas of improvement of administrative regulation of the recreational management subjects work with the attraction of medical resources

\begin{tabular}{|c|c|}
\hline $\begin{array}{c}\text { Areas of } \\
\text { administrative } \\
\text { regulation }\end{array}$ & Task \\
\hline Legislative & $\begin{array}{l}\text { - approval effective mechanisms of controlling the extraction of natural } \\
\text { resources; } \\
\text { - creation of priority development territories for entrepreneurship on the } \\
\text { basis of resorts; } \\
\text { - simplification of methodological legislative basis for the estimation of } \\
\text { the rent fee for the extraction and use of natural resources }\end{array}$ \\
\hline $\begin{array}{l}\text { Administrative- } \\
\text { managerial }\end{array}$ & $\begin{array}{l}\text { - distribution of powers of the specialized control bodies of the } \\
\text { recreational management subjects to the local level; } \\
\text { - recreational management subjects audit of using natural resources; } \\
\text { - development of effective investment attraction programs; } \\
\text { - formation modern system of statistical indicators }\end{array}$ \\
\hline $\begin{array}{l}\text { Administrative and } \\
\text { economic }\end{array}$ & $\begin{array}{l}\text { - provision of loan conditions, subsidizing of the recreational } \\
\text { management subjects, aimed at modernizing equipment for extraction } \\
\text { and production of natural resources; } \\
\text { - financing research of technology development for effective use of } \\
\text { natural resources of the recreational management subjects }\end{array}$ \\
\hline $\begin{array}{l}\text { Administrative- } \\
\text { ecological }\end{array}$ & $\begin{array}{l}\text { - expediency extraction of natural resources in terms of their } \\
\text { polyfunctionality; } \\
\text { - establishment volumes of extraction of natural resources; } \\
\text { - environmental audit recreational management subjects that using } \\
\text { natural resources; } \\
\text { - standardization and certification of products made from natural } \\
\text { resources }\end{array}$ \\
\hline $\begin{array}{l}\text { Administrative and } \\
\text { social }\end{array}$ & $\begin{array}{l}\text { - public control information of using natural resources, which must be } \\
\text { made public by the authorities in the manner specified by the legislation; } \\
\text { - social component in obtaining properties from the use of natural } \\
\text { resources }\end{array}$ \\
\hline
\end{tabular}

Source: compiled by the authors by [11-13].

Therefore, in our opinion, it is expedient to use a unified approach to administering the work of recreational management subjects by conducting an economic assessment of the total use natural resources taking into account extraction, use in sanatorium treatment and the manufacture of products through the use of eco-management tools, namely, the economic analysis of all parties to the organizational , production process and product movement in terms of the concept of the environmental life cycle, carrying out of economic and environmental auditing activities of recreational management subjects.

The next step should be an economic assessment of recreational management subjects work in the recreation and tourist area, starting with the costs of permits and licenses, and ending with the redistribution of taxes to the local and state budget and projected expenditures in the form of benefits for the development of ecologically-driven entrepreneurship in this territory. 
Thus, the main task of administrative management of natural recreational resources should be:

- implementation of effective current and future use of natural resources in sanatorium treatment, medical rehabilitation, recreation of the population;

- provision of rational extraction, use and protection of natural resources;

- creation of favorable conditions for treatment, prevention of diseases and rest of people;

- improvement system of environmental protection measures, the creation of districts and zones of sanitary (mining and sanitary) protection of resorts;

- provision of privileges and tax holidays for the development of recreational management subjects ecologically oriented activities.

So, administrative management in recreational and tourist nature use should be carried out in the following areas:

- compliance with the requirements of the legislation on extraction of minerals;

- transfer the right of state control over compliance with these requirements to the local level;

- improvement system of fiscal and tax control over the recreational management subjects work, that using recreation resources;

- improvement financial regulation by attracting private entrepreneurship in this area, observing the requirements of environmental quality standards, technology standards; product quality standards; ecological certification, etc .;

- distribution taxes from economic activities not only to the state budget, but also to local ones. At the same time, taxes that come to the local budget should be used as subsidies to improve the ecological state of the same territory.
Conclusions and further research. Integrated management of recreation resources and the recreational management subjects should provide for the implementation of a number of horizontal functions that are specific to the type of administrative activity that affects the use of the national resources in the recreational management subjects of various ownership forms. To do this, it is necessary to ensure simultaneous, common, in one economic-ecological plane for all administrative subjects horizontal and vertical branches of compliance with the principles of inclusiveness in nature management:

- development of regulatory and legislative framework in the area: ownership of natural resources, their use, protection and development of entrepreneurship;

- accounting for all natural resources in economic circulation and inventories, along with their recreational management subjects use, potential inventories of natural resources that can be put into economic circulation and their valuations in cash equivalent;

- issuance of permits for the extraction of recreational resources, which contains ecological and economic substantiation of the volumes of extraction of recreation resources without harm for environment;

- monitoring the state of natural recreation resources, ecological and economic indicators of subjects that use them for alternative directions of activity;

- introduction of legally-established administrative, administrative-economic, administrative-ecological and administrativesocial levers of control over the recreational management subjects activities;

- ecological control, examination of the state of natural recreational resources and audit recreational management subjects;

- ecological and economic forecasting and planning recreational management subjects use natural resources. 


\section{REFERENCE}

1. Burkinskyi B.V., Martienko A.I., Khumarova N.I. (2017). Institutional framework for improvement of ownership relations with recreational and tourist resources Odessa: IMPEERNASU [in Ukrainian]

2. Velichko V.V., Beketova O.M., (2013). Organization of recreation services. Harkiv: HNUMG [in Ukrainian]

3. Geiz V.M., Ostashko T.O., Shunkaryk L.V. (2014). Assessment of the impact of the Association Agreement / FTA between Ukraine and the EU on the Ukrainian economy. Retrieved from: ief.org.ua/docs/sr/282.pdf [in Ukrainian]

4. Martiienko A.I. (2011). Theoretical basis of the development of relations of ownership of natural resources. Odessa: IMPEERNASU [in Ukrainian]

5. Danilishin B.M. (2003) .Natural resource rent and rental policy in Ukraine. Ekonomika Ukrainu, 4, 4-11 [in Russian]

6. Samans R., Blanke J., Drzeniek Hanouz M. (2017). The Inclusive Growth and Development Report. World Economic Forum: Geneva, 2017.

7. Ranieri R., Ramos R. A. (2013). Inclusive Growth: Building up a Concept. International Policy Centre for Inclusive Growth United Nations Development Programme.

8. Environment (2018). The World Bank in Europe and Central Asia. Retrieved from https://data.worldbank.org. Hebrew]

9. Central Bureau of Statistics of Israel (2018). Retrieved from: http://cbs.gov.il [in

10. Economic of Israel (2017). Retrieved from: http://cbs.gov.il [in Hebrew] Ukrainian]

11. Tax Code of Ukraine (2018). Retrieved from : https://zakon.help/law/2755-VI [in

12. Chemikal le-Israel signed a salt collection contract to save Dead Sea hotels (2018). Retrieved from: http://newsru.co.il/finance/ [in Hebrew]

13. The State Statistics Service of Ukraine (2018). National accounts. Retrieved from. Retrieved from: http://www.ukrstat.gov.ua [in Ukrainian]

14. Mineral resources of Ukraine (2018). Retrieved from: www/geoinf.kiev.ua [in Ukrainian]

15. Center for the State Cadastre (2018). Retrieved from: http://kurort.gov.ua/index.php/uk/derzhavnij-kadastr [in Ukrainian]

16. Consolidated Budget of Ukraine (2018). Retrieved from: https://index.minfin.com.ua/ua/finance/budget [in Ukrainian] 


\section{ЛІТЕРАТУРА}

1. Буркинській Б.В., Мартієнко А.І., Хумарова Н.I. Інституціональні засади вдосконалення відносин власності на рекреаційно-туристичні ресурси. Одеса: ІПРЕЕД. 2017. $240 \mathrm{c}$.

2. Величко В.В. Бекетова О.М. Організація рекреаційних послуг. Харків: ХНУМГЗ. 2013. 202 c.

3. Гейць В.М., Осташуо Т.О., Шинкарук Л.В. Оцінка впливу Угоди про асоціацію/3ВТ між Україною та СС на економіку України. URL: ief.org.ua/docs/sr/282.pdf

4. Мартієнко А.I. Теоретичні основи розвитку відносин власності на природні ресурси. Одеса: ІПРЕЕД. 2011. 392 с

5. Данилишин Б.М., Мищенко В.И. Природноресурсная рента и рентная политика в Украине. Экономика Украины 2003, № 4. С. 4-11.

6. Samans R., Blanke J., Drzeniek Hanouz M. The Inclusive Growth and Development Report. World Economic Forum: Geneva, 2017. p. viii.

7. Ranieri R., Ramos R. A. Inclusive Growth: Building up a Concept: International Policy Centre for Inclusive Growth United Nations Development Programme, 2013.

8. Всесвітній банк.2018. URL: https://data.world.

9. Central Bureau of Statistics of Israel. 2018. URL:: http://cbs.gov.il.

10. Economic of Israel. 2017. URL: http://cbs.gov.il.

11. Податковий Кодекс України. URL: https://zakon.help/law/2755-VI

12. Chemikal le-Israel signed a salt collection contract to save Dead Sea hotels. 2018. URL: http://newsru.co.il/finance.

13. Державна служба статистики України. $2018 . \quad$ URL: http://www.ukrstat.gov.ua/operativ/oper_new.html.

14. Мінеральні ресурси України. 2018. URL: www/geoinf.kiev.ua.

15. Центр ведення Державного кадастру природних лікувальних ресурсів. 2018. URL: http://kurort.gov.ua/index.php/uk/derzhavnij-kadastr

16. Зведений бюджет https://index.minfin.com.ua/ua/finance/budget. 